\title{
PELAKSANAAN PENCATATAN PERKAWINAN PADA DINAS KEPENDUDUKAN DAN PENCATATAN SIPIL
}

\author{
Oleh \\ Dewa Putu Tagel \\ Dosen Jurusan Hukum Fakultas Dharma Duta IHDN Denpasar
}

\begin{abstract}
Pencatatan perkawinan memegang peranan yang sangat menentukan dalam suatu perkawinan karena pencatatan perkawinan merupakan suatu syarat diakui dan tidaknya perkawinan oleh negara. Bila suatu perkawinan tidak dicatat maka perkawinan tersebut tidak diakui oleh negara, begitu juga sebagai akibat yang timbul dari perkawinan tersebut. Berdasarkan Peraturan Pemerintah Nomor 9 Tahun 1975 ini, maka pencatatan perkawinan dilakukan oleh 2 (dua) instansi pemerintah, yaitu Kantor Urusan Agama (KUA) bagi mereka yang beragama Islam, dan Kantor Catatan Sipil (KCS) bagi mereka yang bukan beragama Islam. Pentingnya pencatatan perkawinan bagi keabsahan perkawinan, melindungi warga negara dalam membina keluarga, memberikan kepastian hukum dan kekuatan hukum bagi suami istri dan anak-anak, memberikan jaminan dan perlindungan terhadap hak-hak tertentu yang timbul karena perkawinan antara lain hak untuk mewaris dan sebagainya.

Kata Kunci : Pencatatan Perkawinan, Catatan Sipil.
\end{abstract}

\section{Pendahuluan}

Perkawinan merupakan suatu ikatan yang sah untuk membina rumah tangga dan keluarga sejahtera bahagia dimana kedua suami istri memikul amanah dan tanggung jawab terhadap keduanya dan anak-anak mereka. Setelah diundangkannya Undang-undang Nomor 1 Tahun 1974 Tentang Perkawinan, banyak disinggung perihal masalah kekeluargaan yang berhubungan erat dengan suatu dasar perkawinan sebagaimana yang dirumuskan dalam Pasal 1, sebagai berikut "Perkawinan adalah ikatan lahir bathin antara seorang pria dan seorang wanita sebagai suami istri dengan tujuan membentuk keluarga (rumah tangga) yang bahagia dan kekal berdasarkan Ketuhanan Yang Maha Esa”.

Pada dasarnya pelaksanaan perkawinan warga masyarakat Indonesia sangat dipengaruhi oleh hukum adat. Hal ini dikarenakan masyarakat beraneka ragam suku bangsanya, sudah pasti beraneka ragam pula hukum adat yang hidup di tanah air Indonesia. Pengertian perkawinan dalam hukum adat adalah suatu ikatan antara seorang lakilaki dengan seorang wanita untuk membentuk rumah tangga yang dilaksanakan secara adat dengan melibatkan keluarga kedua belah pihak, saudara maupun kerabat (Soerojo Wignjodipoero, 1988:55). Dalam hukum adat, perkawinan itu bukan hanya merupakan peristiwa penting bagi mereka yang masih hidup saja, tetapi perkawinan yang merupakan peristiwa yang berarti serta yang sepenuhnya mendapat perhatian dan diikuti oleh arwah-arwah para leluhur kedua belah pihak (Soerojo Wignjodipoero, 1988:155).

Peristiwa perkawinan di Indonesia tidak terlepas dari ketentuan agama, undang-undang yang berlaku maupun hukum adat masing-masing warga masyarakat. Apabila diteliti ketentuan mengenai sahnya suatu perkawinan dalam Undang-undang Perkawinan, maka dapat diketahui bahwa sahnya perkawinan apabila dilakukan menurut hukum masing-masing agama dan kepercayaannya serta tiap-tiap perkawinan dicatat menurut peraturan perundang-undangan yang berlaku. Hal ini dapat dilihat dalam Pasal 2 Undang-undang Nomor 1 Tahun 1974, yang menyatakan bahwa:

(1) Perkawinan adalah sah, apabila dilakukan menurut hukum masing-masing agamanya dan kepercayaannya itu. 
(2) Tiap-tiap perkawinan dicatat menurut peraturan perundang-undangan yang berlaku.

Berdasarkan ketentuan tersebut, maka untuk sahnya perkawinan itu haruslah menurut hukum agama dan kepercayaan dari masingmasing orang yang akan melaksanakan perkawinan dan dilakukan pencatatan perkawinan tersebut, kalau tidak maka perkawinan itu tidak sah.

Pencatatan perkawinan sebagaimana dimaksud dalam Pasal 2 ayat (2) tersebut bertujuan untuk:

a. Tertib administrasi perkawinan

b. Memberikan kepastian dan perlindungan terhadap status hukum suami, isteri maupun anak

c. Memberikan jaminan dan perlindungan terhadap hak-hak tertentu yang timbul karena perkawinan seperti hak waris, hak untuk memperoleh akte kelahiran, dan lain-lain.

Pencatatan perkawinan memegang peranan yang sangat menentukan dalam suatu perkawinan karena pencatatan perkawinan merupakan suatu syarat diakui dan tidaknya perkawinan oleh negara. Bila suatu perkawinan tidak dicatat maka perkawinan tersebut tidak diakui oleh negara, begitu juga sebagai akibat yang timbul dari perkawinan tersebut. Bagi yang bersangkutan (mempelai laki-laki dan wanita) dan petugas agama yang melangsungkan perkawinan tersebut dapat dikenakan ketentuan pidana sebagaimana diatur dalam Pasal 45 Peraturan Pemerintah Nomor 9 Tahun 1975.

Saidus Syahar (1981:108) menyatakan bahwa pada hakekatnya tujuan dari pencatatan perkawinan antara lain :

1. Agar ada kepastian hukum dengan adanya alat bukti yang kuat bagi yang berkepentingan mengenai perkawinannya, sehingga memudahkannya dalam melakukan hubungan dengan pihak ketiga.

2. Agar lebih terjamin ketertiban masyarakat dalam hubungan kekeluargaan sesuai dengan akhlak dan etika yang dijunjung tinggi oleh masyarakat dan negara.

3. Agar ketentuan Undang-undang yang bertujuan membina perbaikan sosial lebih efektif.

4. Agar nilai-nilai norma keagamaan dan adat serta kepentingan umum lainnya sesuai dengan dasar negara Pancasila lebih dapat ditegakkan.

Berdasarkan tujuan pencatatan perkawinan tersebut, maka masyarakat harus mencatatkan perkawinan yang dilakukannya untuk mendapatkan kepastian hukum sesuai dengan peraturan perundang-undangan yang berlaku. Pencatatan perkawinan yang diharapkan oleh peraturan perundang-undangan tersebut, tidaklah efektif. Hal ini dapat dilihat banyak masyarakat yang enggan untuk mencatatkan perkawinannya. Banyak faktor yang menyebabkan masyarakat tidak mencatatkan perkawinan, antara lain :

1. Keperluan poligami

2. Perkawinan yang dilakukan secara agama dan kepercayaannya sudah dianggap sah oleh masyarakat meskipun tanpa pencatatan perkawinan

3. Ketidaktahuan masyarakat terhadap fungsi dari akta perkawinan

4. Perkawinan dibawah umur

Apabila kita lihat dalam peraturan pelaksana dari Undang-undang Nomor 1 Tahun 1974 Tentang Perkawinan, yaitu Peraturan Pemerintah Nomor 9 Tahun 1975 dalam Pasal 2, menyatakan bahwa :

1. Pencatatan perkawinan dari mereka yang melangsungkan perkawinan menurut agama islam, dilakukan oleh pegawai pencatat perkawinan, sebagaimana dimaksud dalam Undang-undang Nomor 32 Tahun 1946 tentang Pencatatan Nikah, Talak dan Rujuk, yaitu Kantor Urusan Agama setempat (KUA daerah dimana perkawinan dilaksanakan).

2. Pencatatan perkawinan dari mereka yang melangsungkan perkawinan menurut agama dan kepercayaannya itu selain agama Islam, dilakukan oleh pegawai pencatat perkawinan pada Kantor Catatan Sipil, sebagaimana dimaksud dalam peraturan perundang-undangan mengenai pencatatan perkawinan.

Jadi dengan adanya Peraturan Pemerintah Nomor 9 Tahun 1975 ini, maka pencatatan perkawinan dilakukan oleh 2 (dua) instansi pemerintah, yaitu Kantor Urusan Agama (KUA) bagi mereka yang beragama Islam, dan Kantor Catatan Sipil (KCS) bagi mereka yang bukan beragama Islam.

Berdasarkan pembagian tempat pencatatan tersebut, maka KUA menerbitkan buku nikah terhadap perkawinan yang dicatatkan bagi yang beragama Islam sedangkan akta perkawinan dikeluarkan oleh Kantor Catatan Sipil bagi mereka yang beragama selain Islam. Buku nikah yang dikeluarkan oleh KUA diterima langsung oleh kedua mempelai setelah selesai melakukan akad nikah, sedangkan akta perkawinan yang dikeluarkan oleh Kantor Catatan Sipil, diterima kedua mempelai 
beberapa hari setelah upacara perkawinan. Hal ini dapat dilihat pada masyarakat Hindu di Bali.

HJ. Nana Cu' Ana (2006) dalam penelitiannya yang berjudul "Pencatatan Perkawinan Menurut Hukum Adat Pada Suku Dayak di Desa Kumpang Kecamatan Toho Kabupaten Pontianak", memberikan gambaran tentang faktor-faktor yang menyebabkan masyarakat tidak mencatatkan perkawinan, antara lain:

1. Perkawinan dianggap sah apabila dilaksanakan secara agama, sedangkan pencatatan hanya bersifat administratif

2. Adanya biaya yang mahal

3. Menghindari birokrasi yang berbelit-belit dan memerlukan waktu yang cukup lama

4. Dengan memiliki surat keterangan nikah dari Kepala Desa, masyarakat bisa mengurus akta kelahiran.

Sedangkan akibat hukum perkawinan yang tidak dicatatkan, antara lain :

1. Perkawinan yang dilaksanakan merupakan perkawinan dibawah tangan

2. Suami istri tersebut oleh Undang-undang dianggap tidak terikat oleh tali perkawinan

3. Anak-anak yang dilahirkan dari hasil perkawinan tersebut bukanlah anak sah menurut undangundang

4. Tidak bisa melakukan urusan birokrasi dengan pejabat negara.

Nana Fitriana (2012) dalam penelitiannya yang berjudul "Masalah Pencatatan Perkawinan Beda Agama Menurut Pasal 35 Huruf a Undangundang Nomor 23 Tahun 2006 Tentang Administrasi Kependudukan (Suatu Analisa Kasus Nomor 527/ Pdt/P/2009/PN.Bgr. dan Nomor 111/Pdt.P/2007/ PN.Bgr.)", memberikan gambaran bahwa apabila terjadi perkawinan beda agama, maka yang bersangkutan dapat mengajukan permohonan pencatatan perkawinan melalui Pengadilan Negeri berdasarkan ketentuan Pasal 35 huruf a Undangundang Nomor 23 Tahun 2006.

Mengingat pentingnya pencatatan perkawinan bagi keabsahan perkawinan, melindungi warga negara dalam membina keluarga, memberikan kepastian hukum dan kekuatan hukum bagi suami istri dan anak-anak, memberikan jaminan dan perlindungan terhadap hak-hak tertentu yang timbul karena perkawinan antara lain hak untuk mewaris dan sebagainya. Maka sudah sepantasnya dilakukan upaya baik dari pemerintah maupun masyarakat itu sendiri untuk mendaftarkan dan mencatatkan perkawinan sesuai dengan ketentuan yang berlaku.

Berdasarkan uraian tersebut, maka tulisan ini membahas tentang pelaksanaan pencatatan perkawinan serta faktor-faktor yang mempengaruhi pelaksanaan pencatatan perkawinan tersebut pada Dinas Kependudukan dan Pencatatan Sipil.

\section{Pembahasan}

2.1 Pelaksanaan Pencatatan Perkawinan Pada masa setelah berlakunya Undangundang Nomor 1 Tahun 1974 tentang Perkawinan, maka perkawinan harus dicatatkan menurut peraturan perundang-undangan yang berlaku. Hal tersebut terlihat dalam Pasal 2 ayat (2) Undangundang Nomor 1974 yang menyatakan bahwa "tiap-tiap perkawinan dicatat menurut peraturan perundang-undangan yang berlaku".

Apabila kita lihat dalam peraturan pelaksana dari Undang-undang Nomor 1 Tahun 1974 Tentang Perkawinan, yaitu Peraturan Pemerintah Nomor 9 Tahun 1975 dalam Pasal 2, menyatakan bahwa :

1. Pencatatan perkawinan dari mereka yang melangsungkan perkawinan menurut agama islam, dilakukan oleh pegawai pencatat perkawinan, sebagaimana dimaksud dalam Undang-undang Nomor 32 Tahun 1946 tentang Pencatatan Nikah, Talak dan Rujuk, yaitu Kantor Urusan Agama setempat (KUA daerah dimana perkawinan dilaksanakan).

2. Pencatatan perkawinan dari mereka yang melangsungkan perkawinan menurut agama dan kepercayaannya itu selain agama Islam, dilakukan oleh pegawai pencatat perkawinan pada Kantor Catatan Sipil, sebagaimana dimaksud dalam peraturan perundang-undangan mengenai pencatatan perkawinan.

Jadi dengan adanya Peraturan Pemerintah Nomor 9 Tahun 1975 ini, maka pencatatan perkawinan dilakukan oleh 2 (dua) instansi pemerintah, yaitu Kantor Urusan Agama (KUA) bagi mereka yang beragama Islam, dan Kantor Catatan Sipil (KCS) bagi mereka yang bukan beragama Islam.

Pelaksanaan pencatatan perkawinan merupakan salah satu implementasi dari Pasal 2 ayat (2) Undang-undang Nomor 1 Tahun 1974 tentang Perkawinan, yang menyatakan bahwa "tiap-tiap perkawinan dicatat menurut peraturan perundang-undangan yang berlaku". Pencatatan perkawinan tersebut bertujuan untuk : 
a. Tertib administrasi perkawinan

b. Memberikan kepastian dan perlindungan terhadap status hukum suami, istri maupun anak

c. Memberikan jaminan dan perlindungan terhadap hak-hak tertentu yang timbul karena perkawinan seperti hak waris, hak untuk memperoleh akte kelahiran, dan lain-lain.

Saidus Syahar (1981:108) menyatakan bahwa pada hakekatnya tujuan dari pencatatan perkawinan antara lain :

1. Agar ada kepastian hukum dengan adanya alat bukti yang kuat bagi yang berkepentingan mengenai perkawinannya, sehingga memudahkannya dalam melakukan hubungan dengan pihak ketiga.

2. Agar lebih terjamin ketertiban masyarakat dalam hubungan kekeluargaan sesuai dengan akhlak dan etika yang dijunjung tinggi oleh masyarakat dan negara.

3. Agar ketentuan Undang-undang yang bertujuan membina perbaikan sosial lebih efektif.

4. Agar nilai-nilai norma keagamaan dan adat serta kepentingan umum lainnya sesuai dengan dasar negara Pancasila lebih dapat ditegakkan.

Ketentuan mengenai pencatatan perkawinan pada masa sebelum berlakunya Undang-undangan Nomor 1 Tahun 1974 tentang Perkawinan, telah ada peraturan yang mengatur mengenai pencatatan perkawinan, yaitu Undangundang Nomor 22 Tahun 1946 tentang Pencatatan Nikah, Talak dan Rujuk jo Undang-undang Nomor 32 Tahun 1954 tentang Penetapan Berlakunya Undang-undang Nomor 22 Tahun 1946.

Undang-undang Nomor 22 Tahun 1946 tentang Pencatatan Nikah, Talak dan Rujuk ini sebelum adanya Undang-undang Nomor 32 Tahun 1954, hanya berlaku untuk daerah Jawa dan Madura. Setelah berlakunya Undang-undang Nomor 32 Tahun 1954, maka Undang-undang Nomor 22 Tahun 1946 ini berlaku juga untuk seluruh luar daerah Jawa dan Madura.

Pada masa itu suatu pencatatan perkawinan bukanlah suatu keharusan bagi suatu perkawinan. Hal ini dapat terlihat pada Pasal 1 ayat (1) Undang-undang Nomor 22 Tahun 1946 yang menyatakan bahwa "Nikah yang dilakukan menurut agama Islam, selanjutnya disebut nikah, diawasi oleh pegawai pencatat nikah yang diangkat oleh Menteri Agama atau Pegawai yang ditunjuk olehnya". Dalam pasal tersebut terlihat bahwa pegawi pencatat nikah itu hanya bertugas mengawasi terlaksananya perkawinan, agar perkawinan itu berlangsung menurut ketentuanketentuan agama Islam.

Apabila kita lihat dalam Pasal 2 Peraturan Pemerintah Nomor 9 Tahun 1975 tentang Peraturan Pelaksana Undang-undang Nomor 1 Tahun 1974 Tentang Perkawinan, menyatakan bahwa :

1. Pencatatan perkawinan dari mereka yang melangsungkan perkawinan menurut agama islam, dilakukan oleh pegawai pencatat perkawinan, sebagaimana dimaksud dalam Undang-undang Nomor 32 Tahun 1946 tentang Pencatatan Nikah, Talak dan Rujuk, yaitu Kantor Urusan Agama setempat (KUA daerah dimana perkawinan dilaksanakan)

2. Pencatatan perkawinan dari mereka yang melangsungkan perkawinan menurut agama dan kepercayaannya itu selain agama Islam, dilakukan oleh pegawai pencatat perkawinan pada Kantor Catatan Sipil, sebagaimana dimaksud dalam peraturan perundang-undangan mengenai pencatatan perkawinan.

Berdasarkan uraian tersebut, maka pencatatan perkawinan bagi masyarakat yang beragama Hindu dilakukan pada Kantor Catatan Sipil. Oleh karena itu, pencatatan perkawinan bagi masyarakat yang beragama Hindu di Kabupaten Gianyar dilaksanakan pada Kantor Dinas Kependudukan dan Pencatatan Sipil Kabupaten Gianyar. Kewenangan Kantor Dinas Kependudukan dan Pencatatan Sipil Kabupaten Gianyar melakukan pencatatan perkawinan berdasarkan :

a. Undang-undang Nomor 23 Tahun 2006 tentang Administrasi Kependudukan

b. Undang-undang Nomor 24 Tahun 2013 tentang Perubahan Atas Undang-undang Nomor 23 Tahun 2006 Tentang Administrasi Kependudukan

c. Peraturan Daerah Kabupaten Gianyar Nomor 5 Tahun 2016 tentang Pembentukan dan Susunan Perangkat Daerah

d. Peraturan Bupati Gianyar Nomor 87 Tahun 2016 tentang Susunan Organisasi dan Tata Kerja Dinas Kependudukan dan Pencatatan Sipil Kabupaten Gianyar

Pelaksanaan pencatatan perkawinan pada Dinas Kependudukan dan Pencatatan Sipil Kabupaten Gianyar berlaku secara umum bagi masyarakat selain yang beragama Islam. Pelaksanaan pencatatan perkawinan tersebut merujuk pada ketentuan peraturan perundangundang yang berlaku yaitu Undang-undang Nomor 
1 Tahun 1974 tentang Perkawinan, Undang-undang Nomor 23 Tahun 2006 Tentang Administrasi Kependudukan. Mengenai prosedur dan dasar hukum lebih lanjut tentang pencatatan perkawinan dapat diuraikan sebagai berikut :

\subsubsection{Pencatatan Perkawinan Menurut Undang-} undang Nomor 1 Tahun 1974 Tentang Perkawinan Pada masa setelah berlakunya Undang-undang Nomor 1 Tahun 1974 tentang Perkawinan, maka perkawinan harus dicatatkan menurut peraturan perundang-undangan yang berlaku. Hal tersebut terlihat dalam Pasal 2 ayat (2) Undang-undang Nomor 1 Tahun 1974 yang menyatakan bahwa "Tiap-tiap perkawinan dicatat menurut peraturan perundang-undangan yang berlaku". Dalam penjelasan umum disebutkan bahwa pencatatan perkawinan adalah sama halnya dengan peristiwaperistiwa penting dalam kehidupan seseorang misalnya kelahiran, kematian yang dinyatakan dalam surat-surat keterangan suatu akta resmi yang juga dimuat dalam daftar pencatatan. Menurut K. Wantjik Saleh (1976:16) bahwa "perbuatan pencatatan tidak menentukan sahnya suatu perkawinan, tetapi menyatakan bahwa peristiwa itu memang ada dan terjadi, jadi semata-mata bersifat administratif'.

Apabila kita lihat dalam peraturan pelaksana dari Undang-undang Nomor 1 Tahun 1974, yaitu Peraturan Pemerintah Nomor 9 Tahun 1975 dalam Pasal 2 menyatakan bahwa :

1. Bagi yang beragama Islam pencatatannya dilakukan oleh pegawai pencatat perkawinan, sebagaimana dimaksud dalam Undang-undang Nomor 32 Tahun 1946 tentang Pencatatan Nikah, Talak dan Rujuk, yaitu Kantor Urusan Agama setempat (KUA daerah dimana perkawinan dilaksanakan)

2. Bagi mereka yang bukan Islam, pencatatan dilakukan oleh pegawai pencatat perkawinan pada Kantor Catatan Sipil.

Jadi dengan adanya Peraturan Pemerintah Nomor 9 Tahun 1975 ini, maka pencatatan perkawinan dilakukan oleh 2 (dua) instansi pemerintah, yaitu :

1. Kantor Urusan Agama (KUA), bagi mereka yang beragama Islam.

2. Kantor Catatan Sipil (KCS), bagi mereka yang bukan beragama Islam.

Pasal 3 Peraturan Pemerintah Nomor 9

Tahun 1975 menyatakan bahwa "setiap orang yang hendak melangsungkan perkawinan harus memberitahukan kehendaknya itu, baik secara lisan maupun tertulis kepada pegawai pencatat di tempat perkawinan akan dilangsungkan, dalam jangka waktu sekurang-kurangnya sepuluh hari kerja sebelum perkawinan dilangsungkan".

Kehendak perkawinan harus memuat :

a. Nama

b. Umur

c. Agama atau kepercayaan

d. Pekerjaan

e. Tempat kediaman calon mempelai

f. Apabila salah seorang atau keduanya pernah kawin disebutkan juga nama istri atau nama suami terdahulu

Selanjutnya Pasal 6 Peraturan Pemerintah

Nomor 9 Tahun 1975 menyatakan bahwa :

Pegawai pencatat selain meneliti tentang apakah syarat-syarat perkawinan telah dipenuhi dan apakah tidak terdapat halangan perkawinan menurut undang-undang, dan juga meneliti :

a. Kutipan akta kelahiran calon mempelai

b. Keterangan mengenai nama, agama atau kepercayaan, pekerjaan dan tempat tinggal kedua orang tua calon mempelai

c. Izin tertulis atau izin pengadilan sebagai dimaksud dalam pasal 6 ayat 2, 3, 4 dan 5 Undang-undang Perkawinan

d. Dispensasi pengadilan atau pejabat sebagaimana dimaksud dalam pasal 7 ayat (2) Undang-undang Perkawinan

e. Dispensasi pengadilan atau pejabat

f. Surat kematian istri atau suami atau surat keterangan perceraia bagi perkawinan untuk kedua kalinya atau lebih

g. Surat kuasa otentik atau dibawah tangan yang disahkan oleh pegawai pencatat, apabila salah seorang calon mempelai atau keduanya tidak dapat hadir sendiri karena sesuatu alasan yang penting sehingga diwakilkan orang lain.

Setelah dipenuhinya tata cara dan syaratsyarat pemberitahuan, serta tidak ada halangan perkawinan, pegawai pencata menyelenggarakan pengumuman tentang pemberitahuan kehendak melangsungkan perkawinan di kantor pencatatan perkawinan pada tempat yang sudah ditentukan dan mudah dibaca oleh umum. Sepuluh hari setelah pengumuman perkawinan tersebut, dan selama pengumuman tadi tidak ada pencegahan perkawinan, maka perkawinan bisa dilaksanakan. Pencatatan perkawinan memegang peranan yang sangat menentukan dalam suatu perkawinan karena pencatatan perkawinan merupakan suatu syarat 
diakui dan tidaknya perkawinan oleh negara. Bila suatu perkawinan tidak dicatat maka perkawinan tersebut tidak diakui oleh negara, begitu pula sebagai akibat yang timbul dari perkawinan tersebut. Bahkan bagi yang bersangkutan (mempelai laki-laki dan wanita) dan petugas agama yang melangsungkan perkawinan tersebut dapat dikenakan ketentuan pidana sebagaimana diatur dalam Pasal 45 Peraturan Pemerintah Nomor 9 Tahun 1975.

Menurut Saidus Syahar (1981:108) yang menyatakan bahwa pada hakekatnya tujuan dari pencatatan perkawinan antara lain :

1. Agar ada kepastian hukum dengan adanya alat bukti yang kuat bagi yang berkepentingan mengenai perkawinannya, sehingga memudahkannya dalam melakukan hubungan dengan pihak ketiga,

2. Agar lebih terjamin ketertiban masyarakat dalam hubungan kekeluargaan sesuai dengan akhlak dan etika yang dijunjung tinggi oleh masyarakat dan negara,

3. Agar ketentuan Undang-undang yang bertujuan membina perbaikan sosial lebih efektif,

4. Agar nilai-nilai norma keagamaan dan adat serta kepentingan umum lainnya sesuai dengan dasar negara Pancasila lebih dapat ditegakkan.

Berdasarkan pernyataan tersebut, maka dicatatkan perkawinan akan memberikan perlindungan hukum kepada kedua belah pihak dan memudahkan pembuktian adanya perkawinan. Prosedur dan dasar hukum pencatatan perkawinan dapat diuraikan sebagai berikut :

1. Pasal 2 ayat (2) Undang-undang Nomor 1 Tahun 1974 tentang Perkawinan, menyatakan bahwa "Tiap-tiap perkawinan dicatat menurut peraturan perundang-undangan yang berlaku".

2. Pasal 10 ayat (3) Peraturan Pemerintah Nomor 9 Tahun 1975, menyatakan bahwa "Dengan mengindahkan tata cara perkawinan menurut masing-masing hukum agamanya dan kepercayaannya itu, perkawinan dilaksanakan di hadapan pegawai pencatat dan dihadiri oleh dua orang saksi".

3. Pasal 11 ayat (1) Peraturan Pemerintah Nomor 9 Tahun 1975, menyatakan bahwa "Sesaat setelah dilangsungkan perkawinan sesuai dengan ketentuan-ketentuan Pasal 10 Peraturan Pemerintah ini, kedua mempelai menandatangani akta perkawinan yang telah disiapkan oleh Pegawai Pencatat berdasarkan ketentuan yang berlaku".
4. Pasal 11 ayat (2) Peraturan Pemerintah Nomor 9 Tahun 1975, menyatakan bahwa "Akta perkawinan yang telah ditandatangani oleh mempelai itu, selanjutnya ditandatangani pula oleh kedua saksi dan Pegawai Pencatat yang menghadiri perkawinan dan bagi yang melangsungkan perkawinan menurut agama Islam, ditandatangi pula oleh wali nikah atau yang mewakilinya".

5. Pasal 11 ayat (3) Peraturan Pemerintah Nomor 9 Tahun 1975, menyatakan bahwa "Dengan menandatangani akta perkawinan, maka perkawinan telah tercatat secara resmi".

Menurut Wahyono Darmabrata (2002:3940) bahwa "akta perkawinan adalah suatu alat bukti yang membuktikan tentang terjadinya peristiwa hukum yang berupa peristiwa perkawinan tersebut". Akta perkawinan yang telah ditandatangani disimpan di Kantor Catatan Sipil sebagai arsip, sedangkan yang diterima oleh kedua mempelai adalah Kutipan Akta Perkawinan.

2.1.2 Pencatatan Perkawinan Menurut Undangundang Nomor 23 Tahun 2006 Tentang Administrasi Kependudukan

Pertimbangan dibentuknya Undangundang Nomor 23 Tahun 2006 tentang Administrasi Kependudukan, antara lain :

a. Negara Kesatuan Republik Indonesia berdasarkan Pancasila dan Undang-undang Dasar 1945 berkewajiban memberikan perlindungan dan pengakuan terhadap penentuan status pribadi dan status hukum atas setiap peristiwa kependudukan dan peristiwa penting yang dialami oleh penduduk Indonesia yang berada di dalam dan/atau di luar wilayah negara Kesatuan Republik Indonesia.

b. Untuk memberikan perlindungan, pengakuan, penentuan status pribadi dan status hukum setiap peristiwa kependudukan dan peristiwa penting yang dialami oleh penduduk Indonesia dan warga negara Indonesia yang berada di luar wilayah Negara Kesatuan Republik Indonesia, perlu dilakukan pengaturan tentang Administrasi Kependudukan.

c. Pengaturan tentang Administrasi Kependudukan hanya dapat terlaksana apabila didukung oleh pelayanan yang profesional dan peningkatan kesadaran penduduk, termasuk Warga Negara Indonesia yang berada di luar negeri.

d. Peraturan perundang-undangan mengenai Administrasi Kependudukan yang ada tidak 
sesuai lagi dengan tuntutan pelayanan Administrasi Kependudukan yang tertib dan tidak diskriminatif sehingga diperlukan pengaturan secara menyeluruh untuk menjadi pegangan bagi semua penyelenggara negara yang berhubungan dengan kependudukan.

Tujuan dibenahinya administrasi kependudukan dengan dibentuknya Undang-undang Nomor 23 Tahun 2006 tentang Administrasi Kependudukan adalah agar dapat memberikan pemenuhan hak administratif seperti pelayanan publik serta perlindungan yang berkaitan dengan dokumen kependudukan tanpa adanya perlakuan yang diskriminatif.

Undang-undang Dasar 1945 setelah amandemen ke-empat menjamin setiap orang berhak untuk membentuk sebuah keluarga dan berketurunan melalui perkawinan yang sah (Pasal 28B). kemudian Pasal 29 ayat (2), negara menjamin tiap-tiap warga negara untuk menjalankan agama dan kepercayaannya secara bebas. Berdasarkan hal tersebut, jelas bahwa perkawinan adalah salah satu hak asasi manusia yang dilindungi Undangundang Dasar dan bersifat non-diskriminatif.

Melalui Undang-undang Nomor 23 Tahun 2006 khususnya Pasal 35 huruf a, memberikan pengakuan terhadap perkawinan beda agama di Indonesia, dengan cara memohon penetapan pengadilan yang menjadi dasar dapat dicatatkannya perkawinan beda agama di Kantor Catatan Sipil. Keabsahan perkawinan akan dinilai oleh Hakim Pengadilan Negeri dimana permohonan diajukan.

Perlindungan dan pengakuan atas status pribadi dan status hukum setiap peristiwa kependudukan dan semua peristira penting yang dialami oleh penduduk yang berada di dalam wilayah Indonesia, adalah diberikan oleh negara. Perkawinan merupakan peristiwa penting yang berkaitan dengan status hukum seseorang, dan merupakan hak sipil warga negara. Pencatatan perkawinan adalah tindakan administratif dan bukan syarat sahnya perkawinan, tetapi tetap sangat penting untuk dilakukan karena merupakan bukti autentik terhadap status hukum seseorang. Wujudnya adalah berupa buku nikah atau akta perkawinan, yang menunjukkan perkawinan telah benar-benar terjadi dan sah secara hukum.

Prosedur dan dasar hukum pencatatan perkawinan menurut Undang-undang Nomor 23 Tahun 2006 tentang Administrasi Kependudukan, dapat diuraikan sebagai berikut :
1. Pasal 1 angka 17, menyatakan bahwa "Peristiwa penting adalah kejadia yang dialami oleh seseorang meliputi kelahiran, kematian, lahir mati, perkawinan, perceraian, pengakuan anak, pengesahan anak, pengangkatan anak, perubahan nama, dan perubahan status kewarganegaraan".

2. Pasal 1 angka 23, menyatakan bahwa "Kantor Urusan Agama Kecamatan, selanjutnya disingkat KUAKec., adalah satuan kerja yang melaksanakan pencatatan nikah, talak, cerai, dan rujuk pada tingkat kecamatan bagi penduduk yang beragama Islam".

3. Pasal 34, menyatakan bahwa :

(1) Perkawinan yang sah berdasarkan ketentuan perundang-undangan wajib dilaporkan oleh penduduk kepada istansi pelaksana di tempat terjadinya perkawinan paling lambat 60 (enam puluh) hari sejak tanggal perkawinan.

(2) Berdasarkan laporan sebagaimana dimaksud pada ayat (1), Pejabat Pencatat Sipil mencatat pada Register Akta Perkawinan dan menerbitkan Kutipan Akta Perkawinan.

(3) Kutipan Akta Perkawinan sebagaimana dimaksud pada ayat (2) masing-masing diberikan kepada suami istri.

(4) Pelaporan sebagaimana dimaksud pada ayat (1) dilakukan oleh penduduk yang beragama Islam kepada KUAKec.

(5) Data hasil pencatatan atas peristiwa sebagaimana dimaksud pada ayat (4) dan dalam pasal 8 ayat (2) wajib disampaikan oleh KUAKec. kepada Instansi Pelaksana dalm waktu paling lambat 10 (sepuluh) hari setelah pencatatan perkawinan dilaksanakan.

4. Pasal 35, menyatakan bahwa :

Pencatatan perkawinan sebagaimana dimaksud dalam pasal 34 berlaku pula bagi :

a. Perkawinan yang ditetapkan oleh pengadilan, dan

b. Perkawinan warga negara asing yang dilakukan di Indonesia atas permintaan warga negara asing yang bersangkutan.

5. Pasal 36, menyatakan bahwa "Dalam hal perkawinan tidak dapat dibuktikan dengan Akta Perkawinan, pencatatan dilakukan setelah adanya penetapan Pengadilan".

6. Pasal 37, menyatakan bahwa :

Pencatatan perkawinan di luar wilayah Negara Kesatuan Republik Indonesia 
(4) Pencatatan perkawinan sebagaimana dimaksud pada ayat (1) dan ayat (2) dilaporkan oleh yang bersangkutan kepada Instansi Pelaksana ditempat tinggalnya paling lambat 30 (tiga puluh) hari sejak yang bersangkutan kembali ke Indonesia.

Instansi Pelaksana adalah perangkat Pemerintah Kabupaten/Kota yang bertanggungjawab dan berwenang melaksanakan pelayanan dalam urusan Administrasi Kependudukan (Pasal 1 angka 7 Undang-undang Nomor 23 Tahun 2006.

Selain rujukan peraturan perundangundangan tersebut, pada beberapa Dinas Kependudukan dan Pencatatan Sipil juga mengeluarkan inovasi dalam rangka meningkatkan pelayanan pencatatan perkawinan yang disebut dengan istilah "kado perkawinan" pada Dinas Kependudukan dan Pencatatan Sipil Kabupaten Gianyar, "Kawismara" pada Dinas Kependudukan dan Pencatatan Sipil Kabupaten Klungkung. Masyarakat yang mengikuti inovasi tersebut harus memberitahukan kehendaknya itu kepada pegawai pencatat pada Dinas Kependudukan dan Pencatatan Sipil dalam jangka waktu sekurangkurangnya 5 (lima) hari kerja sebelum perkawinan dilangsungkan. Kehendak perkawinan tersebut harus memuat :

a. Nama

b. Umur

c. Agama atau kepercayaan

d. Pekerjaan

e. Tempat kediaman calon mempelai

f. Apabila salah seorang atau keduanya pernah kawin disebutkan juga nama istri atau nama suami terdahulu

Disamping menyampaikan kehendaknya tersebut, masyarakat juga harus memenuhi syaratsyarat terkait dengan pencatatan perkawinan seperti :

a. Surat keterangan telah terjadinya perkawinan dari pemuka agama/pendeta atau surat perkawinan penghayat kepercayaan yang ditandatangani oleh pemuka penghayat kepercayaan

b. Foto copy KTP calon suami dan istri

c. Kartu Keluarga calon suami istri

d. Foto copy akta kelahiran calon suami istri

e. Akta perceraian/akta kematian asli bagi yang sudah pernah menikah

f. Pas foto $4 \times 6$ hitam putih/berwarna berjajar/ berdampingan sebanyak 2 lembar g. Menghadapkan 2 orang saksi pada saat pelaksanaan pencatatan perkawinan dengan melampirkan foto copy KTP yang berlaku (saksi berusia 21 tahun ke atas)

h. Surat ijin komandan bagi anggota TNI/Polri

i. Paspor bagi suami atau istri orang asing Prosedur pencatatan perkawinan dapat diuraikan sebagai berikut :

1. Pemohon datang sendiri dan tidak bisa diwakilkan ke Dinas Kependudukan dan Pencatatan Sipil untuk mendaftarkan diri sekurang-kurangnya 5 (lima) hari sebelum tanggal perkawinan dan mengambil formulir pelaporan perkawinan

2. Setelah mengisi blanko yang diterima, pemohon menyerahkan blanko dan persyaratan lainnya kepada petugas loket

3. Petugas loket menerima dan meneliti berkas dan memberikan informasi kepada pemohon tentang masa berlaku, lama penyelesaian

4. Apabila berkas belum lengkap maka petugas mengembalikan kepada pemohon untuk dilengkapi (dapat dilengkapi pada saat upacara perkawinan)

5. Petugas loket memberikan paraf pada berkas sebagai tanda sudah lengkap dan menyerahkan berkas kepada register untuk diproses lebih lanjut

6. Petugas meneliti dan mencatat data pemohon dalam register Akta Perkawinan sesuai berkas

7. Petugas meminta tandatangan pelapor dan saksi-saksi pada register akta perkawinan

8. Petugas meneruskan berkas dan register akta perkawinan kepada kasi pencatatan perkawinan untuk diverifikasi

9. Kasi pencatatan perkawinan memeriksa kesesuaian register dengan data pada berkas pemohon

10. Operator komputer menginput data register akta perkawinan ke dalam sistem komputer dengan teliti

11. Setelah memastikan sudah diinput dengan benar, operator komputer mencetak kutipan akta perkawinan pada kertas putih

12. Operator kumputer mencetak kutipan akta perkawinan pada kertas putih dan meneruskan register dan kutipan akta perkawinan kepada kepala bidang pencatatan sipil

13. Kepala bidang pencatatan sipil memverifikasi dan meneliti kesesuaian kutipan akta perkawinan dengan berkas pemohon dan memberikan paraf pada berkas yang telah sesuai 
14.Petugas operator komputer meneruskan kutipan akta perkawinan, register dan berkas kepada petugas di bidang pencatatan sipil untuk diteruskan kepada Kepala Dinas untuk diparaf

15.Kepala Dinas meneliti dan menandatangani kutipan akta perkawinan dan dokumen lainnya

16.Kepala Dinas meneruskan register dan dokumen lainnya kepada petugas arsip untuk disimpan, dan meneruskan kutipan akta perkawinan untuk di stempel selanjutnya diteruskan ke petugas loket penyerahan berkas

17.Petugas arsip menyimpan berkas pada ruang arsip

18.Pemohon pada batas waktu proses yang telah ditentukan mendatangi Loket Pelayanan pada Dinas Kependudukan dan Pencatatan Sipil (dalam hal kado perkawinan, petugas datang langsung ke tempat berlangsungkan perkawinan)

19.Petugas loket menyerahkan Kutipan Akta perkawinan serta dokumen asli lainnya kepada pemohon.

2.2 Faktor-faktor yang Mempengaruhi Pelaksanaan Pencatatan Perkawinan

Kaidah-kaidah kebudayaan merupakan peraturan tentang tingkah laku atau tindakan yang harus dilakukan dalam suatu keadaan tertentu. Dengan demikian maka kaidah sebagai bagian dari kebudayaan, yang mencakup peraturan-peraturan yang beraneka ragam, demikian pula peratuarn hukum. Berlakunya kaidah tersebut di masyarakat tergantung pada kekuatan kaidah tersebut sebagai petunjuk tentang bagaimana seseorang harus bertingkah laku, artinya sampai sejauh mana kaidahkaidah tersebut diterima oleh suatu kelompok masyarakat sebagai suatu petunjuk perilaku yang pantas. Hukum pada umumnya diartikan sebagai keseluruhan peraturan atau kaidah dalam kehidupan bersama, yang dapat dipaksakan pelaksanaannya dengan suatu sanksi (Mertokusumo, 1986 : 37).

Menurut Satjipo Rahardjo (1991 : 5-6) secara garis besar pengertian hukum dapat dikelompokkan menjadi 3 (tiga) antara lain :

a. Hukum dipandang sebagai kumpulan ide atau nilai abstrak,

b. Hukum dilihat sebagai suatu sistem peraturan yang abstrak, maka pusat perhatian adalah hukum sebagai suatu lembaga yang benar-benar otonomi yang bisa kita bicarakan secara subyek sendiri terlepas dengan hal-hal diluar peraturan tersebut, dan c. Hukum dipahami sebagai sarana/alat untuk mengatur masyarakat. Pengertian ini mengaitkan hukum untuk memenuhi kebutuhan-kebutuhan konkrit dalam masyarakat.

Hukum merupakan karya manusia yang berupa norma-norma dan berisikan petunjuk tingkah laku yang mencerminkan kehendak manusia tentang bagaimana seharusnya masyarakat dibina dan kemana harus diarahkan. Hukum adalah norma yang mengajak masyarakat untuk mencapai citacita serta keadaan tertentu tanpa mengabaikan kenyataan. Dengan demikian hukum dibuat dengan penuh kesadaran oleh negara dan ditujukan kepada tujuan tertentu walau pada kenyataan sering antara norma yang ada dengan tingkah laku yang nyata tidak sesuai atau tidak sejalan, ketidaksesuaian tingkah laku sekalipun si pemegang peran kehendak untuk menyesuaikan diri. Adanya ketidakcocokan antar peran yang diharapkan oleh norma dan tingkah laku yang nyata disebabkan karena fungsi hukum tidak lagi sekedar merekam kembali polapola tingkah laku yang terdapat dalam masyarakat, melainkan ingin membentuk pola-pola tingkah laku yang baru, artinya hukum disamping berfungsi sebagai kontrol sosial, sekaligus berfungsi sebagai sarana untuk mewujudkan suatu masyarakat yang dicita-citakan (hukum berfungsi sebagai sosial engineering).

Hans Kelsen memberikan definisi tentang hukum bahwa "Law is a coercive order of human behavior, it is the primary norm which Stipulates the Sanction". Berdasarkan pernyataan tersebut, hukum adalah merupakan suatu perintah yang bersifat memaksa terhadap tingkah laku manusia yang merupakan kaidah primer yang menetapkan sanksi-sanksi. Ini berarti hukum mencerminkan ciriciri positifnya dan berdiri terlepas sama sekali dari pengaruh politik, ekonomi, sosial dan budaya. Sedangkan pernyataan yang sebaliknya diberikan oleh E. Utrecht, dimana hukum adalah himpunan petunjuk hidup, perintah-perintah dan laranganlarangan yang mengatur tata tertib dalam masyarakat dan seharusnya ditaati oleh anggota masyarakat yang bersangkutan, oleh karena pelanggaran petunjuk hidup tersebut dapat menimbulkan tindakan oleh pemerintah atau penguasa masyarakat itu. Ini berarti hukum tidak sekedar dipandang sebagai kaidah-kaidah, melainkan juga sebagai gejala sosial dan sebagai segi dari kebudayaan.

Hukum adalah merupakan norma/kaidah yang dijadikan petunjuk bagi hidup manusia. Oleh 
karena itulah hukum mempunyai kekuatan mengikat. Agar suatu norma, khususnya disini adalah norma hukum dapat diterima oleh kelompok masyarakat, maka harus dapat melembaga (Instituzionalized) dalam diri warga masyarakat. Usaha-usaha untuk menumbuhkan kebudayaan hukum di dalam masyarakat akan dapat mencapai hasil yang baik bila proses pelembagaan dalam hukum dilakukan. Hoebel mengemukakan 4 (empat) fungsi dasar dari hukum yaitu :

a. Menetapkan hubungan-hubungan antar para anggota masyarakat dengan menunjukkan jenisjenis tingkah laku apa yang diperkenankan dan apa yang dilarang,

b. Menentukan pembagian kekuasaan dan merinci siapa-siapakah yang harus mentaatinya dan sekaligus sanksi-sanksi yang tepat dan efektif,

c. Menyelesaikan sengketa-sengketa, dan

d. Memelihara kemampuan masyarakat untuk menyesuaikan diri dengan kondisi-kondisi kehidupannya yang berubah dengan cara merumuskan kembali hubungan antara para anggota masyarakat tersebut.

Berdasarkan penjelasan tersebut, maka dapat dirumuskan apa yang dimaksud dengan budaya hukum. Konsep mengenai budaya hukum pertama kali diperkenalkan oleh Lawrence M. Friedman pada tahun 1969 dan kemudian diperkembangkan lagi oleh beberapa sarjana seperti Daniel S. Lev, khususnya di Indonesia konsep ini dikemukankan oleh Satjipto Rahardjo bersamaan dengan usaha pengembangan studi hukum dan masyarakat (Abdurrahman, 1986 : 85).

Menurut Lawrence M. Friedman, setiap sistem hukum selalu mengandung 3 (tiga) komponen, yaitu komponen struktural, komponen substansial, dan komponen kultural. Komponen struktural dari suatu sistem hukum adalah mencakup berbagai institusi yang diciptakan oleh sistem hukum tersebut. Salah satu diantaranya lembaga tersebut adalah catatan sipil. Dalam kaitan ini termasuk pula tentang struktur organisasinya, landasan hukum bekerjanya, pembagian kompetensi dan lain-lain. Komponen substansial mencakup segala apa saja yang merupakan keluaran dari suatu sistem hukum. Dalam pengertian ini termasuk norma-norma hukum baik yang berupa peraturan, keputusankeputusan, doktrin-doktrin sejauh semuanya digunakan dalam proses yang bersangkutan. Komponen kultur inilah yang oleh Lawrence M. Friedman disebut sebagai the legal culture atau budaya hukum. Dengan kata lain bahwa disamping struktur dan substansi hukum dalam suatu sistem hukum, maka suatu hal lagi yang penting adalah unsur tuntutan atau permintaan. Namun karena Friedman mengalami kesulitan dalam mencari istilah yang tepat untuk unsur tersebut kemudian memilih istilah budaya hukum. Selain dilatarbelakangi oleh tuntutan tersebut dan didorong oleh kepentingan, terlihat juga faktor-faktor seperti ide, sikap, keyakinan, harapan dan pendapat mengenai hukum. Sikap masyarakat yang secara simultan tidak mau melaksanakan suatu produk hukum dapat dikatakan bahwa masyarakat tersebut mempunyai budaya hukum. Dalam suatu komunitas, hukum tidak selalu dipatuhi. Ada nilai-nilai dan sikap-sikap yang menjadi pendorong tidak dipatuhinya hukum, yaitu :

a. Terdapat beberapa peraturan perundangundangan yang kurang begitu mengikat individu

b. Terdapat gagasan seseorang dalam kelompok yang tidak sesuai dengan peraturan atau keinginan pemerintah

c. Adanya keinginan mencapai tujuan dengan cepat walaupun melawan hukum

d. Adanya peraturan yang bertentangan satu dengan yang lain

e. Apabila hukum bertentangan secara tajam dengan nilai-nilai yang diugemi oleh masyarakat (Fakrulloh, 1995 : 130).

Selanjutnya tentang struktur dan substansi merupakan unsur-unsur yang nyata dari suatu sistem hukum. Struktur dari suatu sistem merupakan kerangka kerja, merupakan bentuk yang permanen, bentuk lembaga dari suatu sistem, sedangkan substansi disusun atas peraturan-peraturan yang mengatur bagaimana seharusnya lembaga tersebut bekerja. Struktur dan substansi memang nyatanyata merupakan unsur-unsur dari suatu sistem hukum, namun mereka bukanlah mesin yang menggerakkan karena sifatnya statis. Oleh karena itu, budaya hukum yang merupakan kekuatan sosial yang dapat menggerakkan struktur dan substansi hukum tersebut.

Secara rinci dapat dijelaskan faktor-faktor yang mempengaruhi budaya hukum masyarakat terhadap pencatatan perkawinan di Dinas Kependudukan dan Pencatatan Sipil yang dikelompokkan menjadi 3 bagian yaitu :

\section{Struktur Hukum}

Komponen struktur hukum (legal structure) merupakan unsur nyata dari sistem hukum. hal ini dapat dilihat dari pernyataan Lawrence M. Friedman (1975:14) bahwa structure, to be sure, is one basic and obvious 
element of the legal system... The structure of a system is its skeletal framework, it is the elements shape, the institutional body of the system. Struktur dalam sebuah sistem adalah kerangka permanen, atau unsur tubuh lembaga dengan berbagai fungsinya dalam rangka mendukung bekerjanya sistem hukum tersebut. Komponen struktural dari suatu sistem hukum adalah mencakup berbagai institusi yang diciptakan oleh sistem hukum tersebut. Salah satu diantaranya lembaga tersebut adalah catatan sipil. Dalam kaitan ini termasuk pula tentang struktur organisasinya, landasan hukum bekerjanya, pembagian kompetensi dan lain-lain.

Di Indonesia dikenal adanya satu lembaga catatan sipil yang diusahakan oleh pemerintah. Lembaga catatan sipil ini sebelumnya merupakan kelanjutan dari lembaga catatan sipi pada jaman pemerintahan Kolonial Belanda yang dikenal dengan nama "Burgerlijke Stand" atau dikenal dengan singkatan B.S. dan mengandung arti suatu lembaga yang ditugaskan untuk memelihara daftardaftar atau catatan-catatan guna pembuktian status atau peristiwa-peristiwa penting bagi para warga negara, seperti kelahiran, perkawinan, kematian (Subekti, 1979: 22).

Mengenai peristilahan dari catatan sipil sendiri bukanlah dimaksud sebagai suatu catatan dari orang-orang sipil atau golongan sipil sebagai lawan dari kata golongan militer, akan tetapi catatan sipil itu merupakan suatu catatan yang menyangkut kedudukan hukum seseorang. Dilihat dari kelembagaan catatan sipil, lembaga ini bertugas melakukan pencatatan sipil. Menurut Undangundang Nomor 23 Tahun 2006 tentang Administrasi Kependudukan, pencatatan sipil adalah pencatatan peristiwa penting yang dialami oleh seseorang dalam register pencatatan sipil pada instansi pelaksana.

Oleh karena Negara Indonesia adalah suatau Negara hukum, maka kedudukan hukum dari satu peristiwa penting pada setiap warga negaranya harus jelas dan pasti. Manusia dalam menjalankan hidupnya mengalami peristiwa-peristiwa penting, antara lain : peristiwa perkawinan, peristiwa kelahiran, peristiwa perceraian, peristiwa pengakuan anak, peristiwa pengesahan anak, peristiwa pengangkatan anak, peristiwa perubahan nama, peristiwa perubahan status kewarganegaraan dan peristiwa kematian.

Semua peristiwa seperti yang dikemukan di atas adalah sangat penting artinya karena peristiwa tersebut akan membawa akibat hukum bagi kehidupan orang yang bersangkutan dan juga terhadap orang lain atau pihak ketiga. Setiap peristiwa penting yang terjadi dalam kehidupan manusia secara individu atau keluarga, sangat perlu didaftarkan pada lembaga catatan sipil, oleh karena catatan sipil yang berwenang dan bertugas untuk memberikan kepastian serta membuat catatan selengkap-lengkapnya atas peristiwa-peristiwa yang dialami dan kemudian membukukannya.

Semua daftar dari peristiwa-peristiwa penting tersebut dilakukan bersifat terbuka untuk umum, baik bagi warga Negara Indonesia maupun warga negara asing yang tinggal di Indonesia, sehingga baik yang bersangkutan sendiri maupun orang lain yang berkepentingan dapat mengetahui dan memperoleh bukti serta kepastian tentang perkawinan, kelahiran, perceraian, pengakuan anak, pengesahan anak, pengangkatan anak, perubahan nama, perubahan status kewarganegaraan, dan kematian seseorang.

Berkaiatan dengan pengertian kelembagaan catatan sipil itu ada beberapa pendapat para sarjana yang memberikan pengertian tentang catatan sipil, antara lain :

a. H. F. A. Vollmar berpendapat bahwa, catata sipil adalah suatu lembaga yang diadakan oleh penguasa atau pemerintah yang dimaksudkan untuk membukukan selengkap mungkin dan karena itu memberikan kepastian sebesarbesarnya tentang semua peristiwa yang pentingpenting bagi status keperdataan seseorang seperti perkawinan, kelahiran, pengakuan anak, perceraian, dan kematian.

b. Lie Oen Hock mengartikan catatan sipil adalah suatu lembaga yang bertujuan mengadakan pendaftaran, pencatatan serta pembukuan yang selengkap-lengkapnya dan sejelas-jelasnya serta memberikan kepastian hukum yang sebesarbesarnya atas peristiwa kelahiran, pengakuan, perkawinan, dan kematian (Hock, 1961).

Bertitik tolak dari kedua pendapat mengenai pengertian catatan sipil tersebut di atas, maka dapatlah ditarik suatu pengertian, bahwa catatan sipil adalah suatu lembaga yang sengaja diadakan oleh pemerintah yang bertugas untuk mencatat, mendaftarkan serta membukukan selengkap mungkin tiap peristiwa penting bagi status keperdataan seseorang, seperti perkawinan, kelahiran, pengakuan anak, pengesahan anak, perceraian, perubahan nama dan kematian.

Seluruh peristiwa yang terjadi dalam keluarga yang mempunyai aspek hukum didaftarkan 
dan dibukukan, sehingga baik yang bersangkutan sendiri maupun orang lain yang berkepentingan mempunyai bukti yang otentik tentang peristiwaperistiwa tersebut, sehingga kedudukan hukum seseorang menjadi pasti dan tegas.

Apabila ditelaah lebih lanjut dari pengertian catatan sipil tersebut, maka tujuan catatan sipil itu dapat dilihat dari 4 (empat) sudut pandang, yaitu :

a. Untuk mewujudkan kepastian hukum bagi warga negara

b. Untuk membentuk ketertiban umum

c. Untuk pembuktian

d. Untuk memperlancar aktivitas pemerintah dibidang kependudukan atau administrasi kependudukan

Dalam rangka mewujudkan kepastian hukum, maka semua akta-akta didaftar dan dikeluarkan oleh catatan sipil akan dapat mempunyai kekuatan pasti dan tidak dapt dibantah oleh pihak ketiga. Karena akta-akta yang dibuat oleh lembaga catatan sipil adalah mengikat terhadap mereka yang berkepentingan. Kita ketahui pula suatu negara merupakan negara hukum (rechtstaats), maka akan menghendaki pula adanya masyarakat yang teratur, tertib, aman, dan tentram.

Jadi lembaga ini khusus membantu masyarakat dalam hal yang menyangkut kehidupan hukum seseorang pribadi. Diharapkan lembaga ini akan membantu terciptanya ketertiban umum. Selanjutnya akta-akta yang dibuat dan dikeluarkan oleh catatan sipil ini juga merupakan bukti yang paling kuat dan sempurna oleh sebab itu akta catatan sipil ini bersifat akta otentik yang dibuat oleh pejabat pemerintah menurut ketentuan peraturan yang ada.

Mekanisme dan prosedur Standar Pelayanan Pencatatan Perkawinan Dinas Kependudukan dan Pencatatan Sipil, secara umum dapat dirinci sebagai berikut :

a. Pelapor mengambil nomor antrian, mengantri sesuai nomor

b. Operator melakukan verifikasi persyaratan

c. Operator menginput data perkawinan

d. Operator mencetak draft kutipan akta perkawinan

e. Pelapor memverifikasi draft kutipan akta perkawinan, jika sudah benar, membubuhi tanda tangan

f. Operator mencetak register akta perkawinan

g. Mempelai dan 2 orang saksi menandatangani register akta perkawinan h. Kepala Seksi Perkawinan dan Perceraian memverifikasi berkas persyaratan dan draft kutipan akta perkawinan, jika sudah benar, membubuhkan acc cetak

i. Operator mencetak kutipan akta perkawinan

j. Operator menempelkan foto mempelai pada register, kutipan dan berkas persyaratan akta perkawinan

k. Kepala Seksi Perkawinan dan Perceraian membubuhkan paraf pada kutipan akta perkawinan

1. Kepala Bidang Pelayanan Pencatatan Sipil membubuhkan paraf pada kutipan akta perkawinan

m. Operator menyerahkan kutipan akta perkawinan kepada petugas depan, dan menyimpan berkas persyaratan dan register kutipan akta perkawinan

n. Petugas depan membubuhkan stempel pada kutipan akta perkawinan, kemudian menyerahkan kepada mempelai.

\section{Substansi Hukum}

Komponen substansi hukum (legal substance) terdiri dari aturan substantif dan aturan tentang bagaimana lembaga-lembaga harus bertindak. Hal ini dapat dilihat dari pernyataan Lawrence M. Friedman (1975 : 16) bahwa the substance is composed of substantive rule and rules about how institutions should behave. Substansi yang dimaksud adalah aturan atau norma, substansi juga berarti produk atau aturan baru yang dihasilkan oleh orang yang berada dalam sistem hukum itu, yang dipakai pada waktu melaksanakan. Komponen substansial mencakup segala apa saja yang merupakan keluaran dari suatu sistem hukum. Dalam pengertian ini termasuk norma-norma hukum baik yang berupa peraturan, keputusankeputusan, doktrin-doktrin sejauh semuanya digunakan dalam proses yang bersangkutan.

Dalam substansi hukum ini akan dilihat sahnya suatu perkawinan dan lembaga yang diberikan kewenangan untuk melakukan pencatatan perkawinan. Sebelum membahas tentang sahnya perkawinan, maka terlebih dahulu akan dibahas mengenai arti perkawinan berdasarkan peraturan perundang-undangan dalam hal ini adalah Undangundang Nomor 1 Tahun 1974 tentang Perkawinan. Pasal 1 Undang-undang Nomor 1 Tahun 1974 tentang Perkawinan, menyatakan bahwa perkawinan ialah ikatan lahir bathin antara seorang pria dengan seorang wanita sebagai suami isteri 
dengan tujuan membentuk keluarga (rumah tangga) yang bahagia dan kekal berdasarkan Ketuhanan Yang Maha Esa.

Syarat-syarat perkawinan menurut Undang-undang Nomor 1 Tahun 1974, antara lain :

1. Perkawinan harus di dasarkan atas persetujuan kedua calon mempelai

2. Untuk melangsungkan perkawinan seorang yang belum mencapai umur 21 (dua puluh satu) tahun harus mendapat ijin kedua orang tuanya

3. Dalam hal seorang dari kedua orang tua telah meninggal dunia atau dalam keadaan tidak mempu menyatakan kehendaknya, maka ijin kawin cukup diperoleh dari orang tua yang masih hidup atau dari orang tua yang mampu menyatakan kehendaknya

4. Perkawinan hanya diijinkan jika pihak pria sudah mencapai umur 19 tahun dan pihak wanita sudah mencapai umur 16 tahun

5. Seseorang yang masih terikat perkawinan dengan orang lain tidak dapat kawin lagi kecual tersebut pada Pasal 3 dan Pasal 4 Undangundang ini

6. Apabila suami istri telah bercerai kawin lagi satu dengan yang lain dan bercerai lagi untuk kedua kalinya, maka diantara mereka tidak boleh dilangsungkan perkawinan lagi

7. Bagi wanita yang putus perkawinannya berlaku jangka waktu tunggu.

Apabila diteliti ketentuan mengenai sahnya suatu perkawinan dalam Undang-undang Perkawinan adalah apabila dilakukan menurut hukum masing-masing agamanya dan kepercayaannya itu serta tiap-tiap perkawinan dicatat menurut peraturan perundang-undangan yang berlaku. Sahnya suatu perkawinan itu ditentukan oleh ketentuan agama dan kepercayaan mereka yang melakukan perkawinan, berarti apabila suatu perkawinan yang dilakukan bertentangan dengan ketentuan agama dan kepercayaannya, dengan sendirinya menurut hukum perkawinan belum sah dan tidak mempunyai akibat hukum sebagai ikatan perkawinan.

Masyarakat pada umumnya tidak meresapi sepenuhnya ketentuan agama yang dianut oleh masyarakat itu khususnya untuk fenomena sahnya perkawinan. Dengan demikian untuk sahnya perkawinan, masyarakat pada umumnya telah mengikuti ketentuan agama yang dianutnya. Tetapi perlu diperhatikan bahwa upacara perkawinan menurut agama pada dasarnya merupakan bagian dari keseluruhan upacara perkawinan itu, dengan demikian sebelum dan sesudah nikah terdapat upacara perkawinan yang dilakukan menurut adat setempat. Oleh karena itu untuk sahnya perkawinan itu haruslah menurut ketentuan hukum agama dan kepercayaan dari masing-masing orang yang akan melaksanakan perkawinan dan dilakukan pencatatan perkawinan tersebut, kalau tidak maka perkawinan itu tidak sah.

Ketentuan mengenai pencatatan perkawinan pada masa sebelum berlakunya Undang-undang Nomor 1 Tahun 1974 tentang Perkawinan, telah ada peraturan yang mengatur mengenai pencatatan perkawinan, yaitu Undangundang Nomor 22 Tahun 1946 tentang Pencatatan Nikah, Talak dan Rujuk jo Undang-undang Nomor 32 Tahun 1954 tentang Penetapan Berlakunya Undang-undang Nomor 22 Tahun 1946.

Undang-undang Nomor 22 Tahun 1946 tentang Pencatatan Nikah, Talak dan Rujuk ini sebelum adanya Undang-undang Nomor 32 Tahun 1954, hanya berlaku untuk daerah Jawa dan Madura. Maka setelah adanya Undang-undang Nomor 32 Tahun 1954, Undang-undang Nomor 22 Tahun 1946 ini berlaku juga untuk seluruh luar daerah Jawa dan Madura.

Pada masa itu suatu pencatatan perkawinan bukanlah suatu keharusan bagi suatu perkawinan, hal ini dapat dilihat pada Pasal 1 ayat (1) Undang-undang Nomor 22 Tahun 1946 yang menyatakan bahwa "Nikah yang dilakukan menurut agama Islam, selanjutnya disebut nikah, diawasi oleh pegawai pencatat nikah yang diangkat oleh Menteri Agama atau Pegawai yang ditunjuk olehnya". Dalam Pasal tersebut terlihat bahwa pegawai pencatat nikah itu hanya bertugas mengawasi terlaksananya perkawinan agar perkawinan itu berlangsung menurut ketentuanketentuan agama Islam.

Pada masa setelah berlakunya Undangundang Nomor 1 Tahun 1974 tentang Perkawinan, maka perkawinan harus dicatatkan menurut peraturan perundang-undangan yang berlaku. Hal tersebut dapat dilihat dalam Pasal 2 ayat (2) Undang-undang Nomor 1 Tahun 1974 yang berbunyi "tiap-tiap perkawinan dicatat menurut peraturan perundang-undangan yang berlaku". Apabila kita lihat dalam peraturan pelaksana dari Undang-undang Nomor 1 Tahun 1974, yaitu Peraturan Pemerintah Nomor 9 Tahun 1975 dalam Pasal 2 dinyatakan bahwa:

1. Pencatatan perkawinan dari mereka yang melangsungkan perkawinan menurut agama 
Islam, dilakukan oleh pegawai pencatat perkawinan, sebagaimana dimaksud dalam Undang-undang Nomor 32 Tahun 1946 tentang Pencatatan Nikah, Talak dan Rujuk, yaitu Kantor Urusan Agama setempat (KUA daerah dimana perkawinan dilaksanakan).

2. Pencatatan perkawinan dari mereka yang melangsungkan perkawinan menurut agama dan kepercayaannya itu selain agama Islam, dilakukan oleh pegawai pencatat perkawinan pada Kantor Catatan Sipil, sebagaimana dimaksud dalam peraturan perundang-undangan mengenai pencatatan perkawinan.

Berdasarkan Peraturan Pemerintah

Nomor 9 Tahun 1975 ini, maka pencatatan perkawinan dilakukan oleh 2 (dua) instansi pemerintah, yaitu :

1. Kantor Urusan Agama (KUA), bagi mereka yang beragama Islam

2. Kantor Catatan Sipil (KCS), bagi mereka yang bukan beragama Islam

Pencatatan perkawinan memegang peranan yang sangat menentukan dalam suatu perkawinan karena pencatatan perkawinan merupakan suatu syarat diakui dan tidaknya perkawinan oleh negara. Apabila suatu perkawinan tidak dicatat maka perkawinan tersebut tidak diakui oleh negara, begitu pula sebagai akibat yang timbul dari perkawinan tersebut. Bahkan bagi yang bersangkutan (mempelai laki-laki dan wanita) dan petugas agama yang melangsungkan perkawinan tersebut dapat dikenakan ketentuan pidana sebagaimana diatur dalam Pasal 45 Peraturan Pemerintah Nomor 9 tahun 1975.

Menurut Saidus Syahar (1981 : 108) yang menyatakan bahwa pada hakekatnya tujuan dari pencatan perkawinan antara lain :

a. Agar ada kepastian hukum dengan adanya alat bukti yang kuat bagi yang berkepentingan mengenai perkawinannya, sehingga memudahkannya dalam melakukan hubungan dengan pihak ketiga

b. Agar lebih terjamin ketertiban masyarakat dalam hubungan kekeluargaan sesuai dengan akhlak dan etika yang dijunjung tinggi oleh masyarakat dan negara

c. Agar ketentuan Undang-undang yang bertujuan membina perbaikan sosial lebih efektif

d. Agar nilai-nilai norma keagamaan dan adat serta kepentingan umum lainnya sesuai dengan dasar negara Pancasila lebih dapat ditegakkan
Oleh karena itu dengan dicatatkan perkawinan akan memberikan perlindungan hukum kepada kedua belah pihak dan memudahkan pembuktian adanya perkawinan.

\section{Budaya Hukum}

Komponen budaya hukum (legal culture) merupakan sikap perilaku manusia, kebiasaankebiasaan yang dapat membentuk kekuatankekuatan sosial untuk mentaati hukum atau sebaliknya melanggar hukum. budaya hukum bagian dari budaya pada umumnya berupa adat istiadat, pandangan, cara berpikir dan bertingkah laku, kesemuanya itu dapat membentuk kekuatan sosial yang bergerak mendekati hukum dan caracara tertentu. Hal ini dapat dilihat dari pernyataan Lawrence M. Friedman (1975; 15) bahwa legal culture refers, then, to those parts of general culture, customs, opinion, ways of doing and thinking, that bend social forces toward or away from the law and in particular ways.

Ditinjau dari aspek sosial, perkawinan merupakan suatu dasar bagi terbentuknya suatu keluarga. Sebagaimana kita ketahui, bahwa keluarga adalah merupakan unit terkecil dalam suatu masyarakat. Sebagai suatu lembaga perkawinan itu telah ada sejak kelahiran yang pertama. Disamping itu dengan adanya perkawinan akan membawa akibat perubahan status sosial bagi yang bersangkutan dalam masyarakat, yakni perubahan status dari hidup sendiri menjadi hidup bersama dalam suatu keluarga.

Ditinjau dari segi agama, perkawinan adalah suatu lembaga yang suci dan mulia. Dikatakan suci karena dengan adanya perkawinan akan dapat menghindarkan manusia dari hal-hal yang tidak diinginkan seperti perzinahan dan pemerkosaan. Pengertian ini dapat kita lihat di dalam Adyaya IX, 25 bahwa dengan lembaga perkawinan itu dimaksudkan untuk mengatur hubungan sex yang layak, yaitu suatu hubungan biologis yang diperlukan dalam kehidupan seseorang sebagai suami istri (Pudja, 1975 : 17). Dikatakan mulia karena perkawinan akan membuahkan keturunan yang dapat melanjutkan keturunan dan menghindari manusia dari kepunahan. Disamping hal tersebut dapat dilihat, bahwa setiap dilangsungkannya perkawinan disertai dengan upacara-upacara agama dan bahwa upacara keagamaan inilah yang paling menentukan untuk sahnya suatu perkawinan tersebut. 
Ditinjau dari aspek hukum, perkawinan adalah merupakan suatu perbuatan hukum yang menimbulkan hak dan kewajiban diantara para terkait (suami istri). Sebagai akibat dari aspek yang terkait dalam lembaga perkawinan tersebut timbul pengertian perkawinan yang berbeda-beda tergantung dari segi mana akan meninjaunya.

Subekti mendefinisikan bahwa perkawinan adalah pertalian yang sah antara seorang laki-laku dan seorang perempuan untuk waktu yang lama. Sedangkan R. Soetojo Prawirohamidjojo dan Asis Safiodin (1979: 31), memberikan defini perkawinan sebagai suatu hubungan hukum antara seorang pria dengan seorang wanita untuk hidup bersama yang diakui oleh negara. Kemudian Surojo Wignyodipuro (1979 : 46) memberikan definisi perkawinan adalah salah satu peristiwa yang sangat penting dalam kehidupan masyarakat kita, sebab perkawinan tidak hanya menyangkut wanita dan pria bekal mempelajai saja, tetapi juga orang tua kedua belah pihak, saudara-saudaranya, bahkan keluarga mereka masing-masing. Pendapat demikian juga dikemukakan oleh B. Ter Haar Bzn (1979), dimana perkawinan menurut hukum adat adalah urusan kerabat, urusan keluarga, urusan masyarakat, urusan derajat dan urusan pribadi.

\section{Simpulan}

1. Pelaksanaan pencatatan perkawinan dapat dilihat dari cara mendaftarkan perkawinannya pada catatan sipil. Proses pencatatan perkawinan pada Dinas Kependudukan dan Pencatatan Sipil berdasarkan pada Undang-undang Nomor 1 Tahun 1974, Undang-undang Nomor 23 Tahun 2006, serta Inovasi yang telah ditetapkan oleh Dinas Kependudukan dan Pencatatan Sipil seperti Kawismara, Kado Perkawinan.

2. Faktor-faktor yang mempengaruhi pencatatan perkawinan tersebut antara lain faktor struktur hukum, faktor substansi hukum, dan budaya hukum itu sendiri. Struktur hukum yang dimaksud adalah pencatatan perkawinan dilakukan di Dinas Kependudukan dan Catatan Sipil dengan membawa 2 orang saksi memicu masyarakat enggan untuk melakukan pencatatan perkawinan, substansi hukum yang dimaksud adalah pencatatan perkawinan dalam peraturan perundang-undangan bukanlah salah satu syarat sahnya suatu perkawinan melainkan hanya memberikan kepastian hukum bahwa peristiwa perkawinan tersebut benar terjadi, sedangkan budaya hukum yang dimaksud dapat dilihat dari asumsi masyarakat bahwa sahnya perkawinan dilakukan berdasarkan agama dan kepercayaan, sehingga masyarakat merasa apabila perkawinan tersebut telah dilaksanakan sesuai dengan sahnya perkawinan menurut hukum agama dan kepercayaannya maka perkawinan tersebut adalah sah.

\section{DAFTAR PUSTAKA}

Abdurrahman. Tebaran Pikiran Tentang Studi Hukum dan Masyarakat. Jakarta : Media Sarana Press, 1986.

Cu'Ana, Nana. Pencatatan Perkawinan Menurut Hukum Adat Pada Suku Dayak di Desa Kumpang Kecamatan Toho Kabupaten Pontianak. Tesis. Semarang : Program Studi Magister Kenotariatan Universitas Diponegoro, 2006.

Darmabrata, Wahyono dan Sjarif, Surini Ahlan. Hukum Perkawinan dan Keluarga di Indonesia. Jakarta : Rizkita, 2002.

Fitriana, Nana. Masalah Pencatatan Perkawinan Beda Agama Menurut Pasal 35 Huruf a Undangundang Nomor 23 Tahun 2006 Tentang Administrasi Kependudukan (Suatu Analisa Kasus Nomor 527/Pdt/P/2009/PN.Bgr. dan Nomor 111/Pdt.P/2007/PN.Bgr.). Tesis. Depok : Fakultas Hukum Program Magister Kenotariatan Universitas Indonesia, 2012.

Friedman, Lawrence M. The Legal System : A Social Science Prepective. New York : Russel Foundation, 1975.

Hock, Lie Oen. Lembaga Catatan Sipil. Jakarta : Keng.Po., 1961.

Kaleran, A. G. Ngurah dan Oka, Gusti Agung. Hukum Perkawinan Secara Adat dan Agama Hindu, Denpasar : Surya Jaya, 1968.

Peters, A. G. Hukum dan Perkembangan Sosial (Buku Teks Sosiologi Hukum II). Jakarta : Pustaka Sinar Harapan, 1988.

Pudja, Gde. Pengantar Tentang Perkawinan Menurut Hukum Hindu. Denpasar : Mayasari, 1975.

Rahardjo, Satjipto. Hukum dan Masyarakat. Bandung : Angkasa, 1980.

Rahardjo, Satjipto. Ilmu Hukum. Bandung : PT. Citra Aditya Bakti, 1991.

Rahardjo, Satjipto. Permasalahan Hukum di Indonesia. Bandung: Alumni, 1983.

Saleh, K. Wantjik. Hukum Perkawinan di Indonesia. Jakarta : Ghalia Indonesia, 1976.

Soekanto, Soerjono. Faktor-faktor yang Mempengaruhi Penegakan Hukum. Jakarta : Rajawali Pers, 1983.

Soemardjan, Selo dan Soemardi, Soelaeman. Setangkai Bunga Sosiologi. Jakarta : Yayasan Badan Penerbit Fakultas Ekonomi Universitas Indonesia, 1964.

Subekti dan R. Tjitrosoedobro. Kamus Hukum. Jakarta : Pradnya Paramita, 1979.

Syahar, Saidus. Undang-undang Perkawinan dan Masalah Pelaksanaannya Ditinjau Dari Segi Hukum Islam. Bandung: Alumni, 1981.

Warassih, Esmi. Pranata Hukum Suatu Telaah Sosiologis. Semarang : PT. Suryandaru Utama, 2005.

Wignjodipoero, Soerojo. Asas-asas Hukum Adat. Jakarta : Gunung Agung, 1988.

Windia, Wayan P., dkk, Perkawinan Pada Gelahang di Bali. Bali : Udayana University Press, 2013 